\title{
AC 2007-393: SEISMIC DESIGN OF PIERS AND WHARFS: A CAPSTONE COURSE APPLICATION OF A NEW STANDARD FOR DESIGNING PORT STRUCTURES IN THE UNITED STATES
}

Timothy Mays, The Citadel

Kevin Bower, The Citadel

Robert Dullanty, ATM

Kelly Rutkowski, Applied Technology and Management 


\title{
Seismic Design of Piers and Wharfs: A Capstone Course Application of a New Standard for Designing Port Structures in the United States
}

\begin{abstract}
Pier and wharf structures are governed by the International Building Code ${ }^{1}$ if and only if the pier and wharf structure provides the foundation for a building with public occupancy. Otherwise, the design is outside the scope of the aforementioned document. A uniformly recognized standard has never been available to engineers and most engineers reference various documents including building codes for lateral loads, bridge standards for truck traffic, and marine oil terminal documents for special provisions when designing such structures. ASCE is in the final phases of the development of the first national standard for the seismic design of pier and wharf structures. This paper presents the background information behind the document's development. As part of a structural engineering capstone course at The Citadel, students are designing a pier structure to meet the requirements of the new national standard and the steps of the design are presented as a case study application. In addition, multidisciplinary student work that includes environmental concerns relevant to marine oil terminals is also presented.
\end{abstract}

Introduction

Although other countries (e.g., England, Australia) have well established design standards for pier and wharf type structures, the United States currently has only a few regional standards and no national standard that covers the design of these structures. The $\mathrm{Navy}^{2}$ has developed some of their own standards for ships moored to pier and wharf structures. Seismic Criteria for California Marine Oil Terminals ${ }^{3}$ was released in 1999 and served as the forerunner MOTEMS ${ }^{4}$ to the most comprehensive standard developed for use in the United States to date. According to MOTEMS:

"The purpose of this Code is to establish minimum engineering, inspection and maintenance criteria for MOTs in order to prevent oilspills and to protect public health, safety and the environment. This Code does not, in general, address operational requirements. Relevant provisions from existing codes, industry standards, recommended practices, regulations and guidelines have been incorporated directly or through reference, as part of this Code."

MOTEMS specifications vary based on risk. However, risk is a function of exposed oil, making the standard at least somewhat non applicable to piers and wharfs that are not a part of the marine oil terminal industry. Harn ${ }^{5}$ describes one of the first published applications of this standard and illustrates its application for a large wharf structure. 
ASCE's Seismic Design of Pier and Wharf Structures

In 2005 ASCE began development of the first National Standard regarding the design of all pier and wharf type structures titled Seismic Design of Piers and Wharfs. It is currently in the final phases of development and the lead author of this paper serves as the document's technical editor. The document contains provisions for the seismic design of pier and wharf type structures and includes chapters on analysis, design, and detailing. Where applicable, the standard references other national standards such as ACI $318^{6}$ and AASHTO LRFD Bridge Design Specifications ${ }^{7}$.

Structural Capstone Class at The Citadel

All civil engineering students at The Citadel are required to take a capstone course in one of four areas of their choice:

- Structural Engineering

- Environmental Engineering

- Subdivisions

- Transportation (Evening Students Only)

All students that take the structural engineering capstone class are required to develop plans, specifications, and a concise set of calculations for a group building and an individual project of their choice. Given the lead author's vast design experiences with buildings, bridges, and pier and wharf type structures, students have a variety of choices for their individual project. Most students choose to design a smaller building since the design criteria and standards are the same as for the group project. However, a few students each year have a particular interest in bridge or marine applications elect to design these structures.

A major component of all the capstone classes is multidiscipline activities. Mays and Bower ${ }^{8}$ present the evolution of capstone classes at The Citadel and the methods used by the instructors to incorporate multidisciplinary work.

\section{Spring 2007 Capstone Project in Coastal Engineering}

In the Spring, 2007, two students in the Structural Capstone class will be designing a marina for high seismic loading in accordance with the new ASCE standard (draft) Seismic Design of Piers

and Wharfs. The layout of the marina has been established since the structure is an actual marina (not in a high seismic zone) designed by the lead author. Figure 1 shows a plan view of the marina. Figure 2 shows a section through a typical finger pier. Only schematic drawings will be given to the students and the students will be required to design for all loads including:

- Dead

- Live

- Earthquake

- Wind 
- Current

- Impact

All environmental loading other than seismic will be determined using MOTEMS ${ }^{4}$. Detailing of the structure will be in accordance with ACI $318^{6}$ and AASHTO LRFD Bridge Design Specifications ${ }^{7}$.

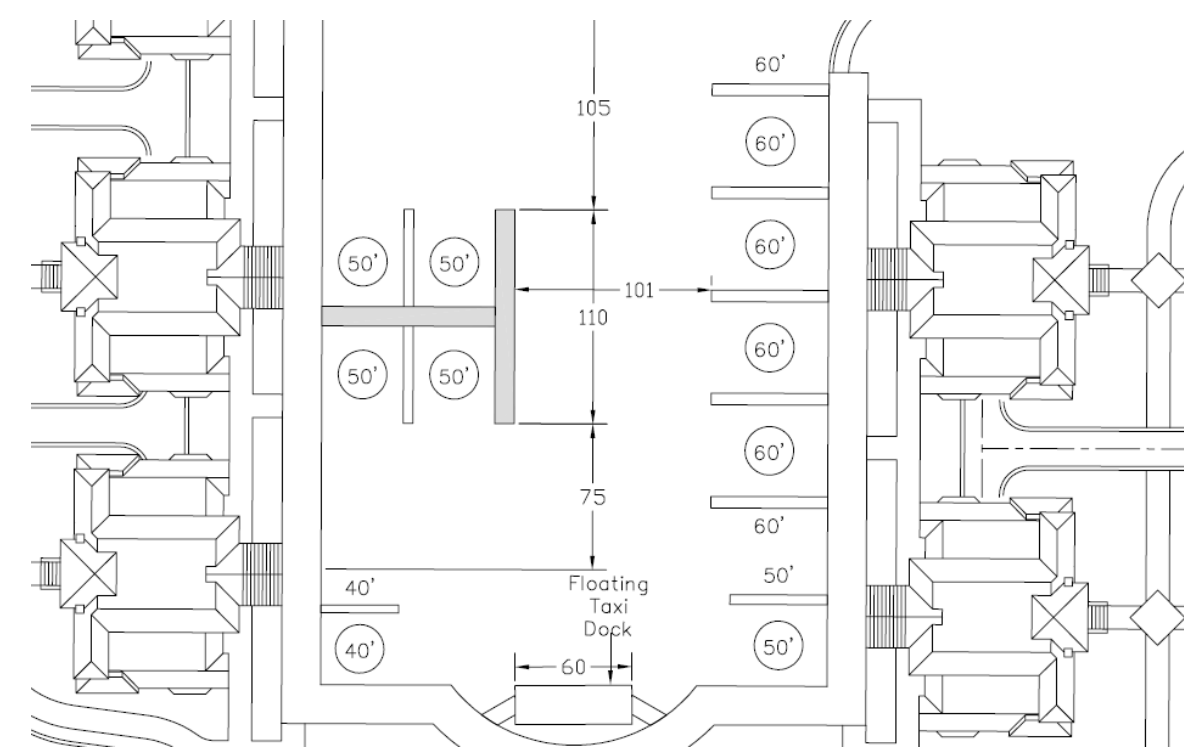

Figure 1. Plan view of capstone marina design.

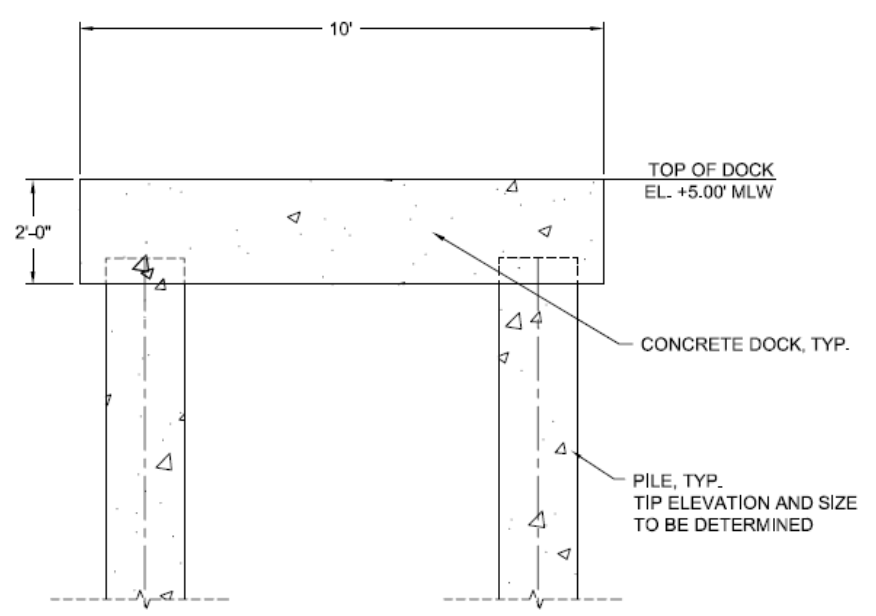

Figure 2. Section through typical finger pier.

Another unique aspect of this project is that undergraduate student research on the design of precast prestressed piling in seismic areas will be directly referenced in the design process. In 2005-2006, Tom Hill (Mays and Hill ${ }^{9}$ ) analyzed 2,500 piles to determine the seismic 
performance of piling in South Carolina. This research has led to a change in the building code used in South Carolina and modifications to the state's bridge code.

Since this paper summarizes the development of a capstone course project in coastal engineering, only anticipated results can be discussed here. It is expected that the students working on the project will appreciate the vastly different loading conditions used for marinas as compared to those used in other classes in the curriculum that teach building design. Design for dead and live loading for fixed pier type structures will be somewhat similar to what is taught in reinforced concrete design for cast-in-place one way slabs. Emphasis will be placed on concrete cracking and corrosion protection of reinforcing steel. Environmental loads will be treated as acting on the piers themselves (i.e., seismic) and as the result of mooring system loads (i.e., wind, current, wave) that keep the boats tied to the piers. Berthing loads to include impact will also be considered by the students working on the project. Lateral forces on the pier shall be resisted by piles embedded in the underlying soil. The students will be introduced to soil spring modeling (i.e., p-y curves), but will treat the condition using a lower bound point of fixity for bending and an upper bound point of fixity for shear demand.

\section{Additional Multidisciplinary Work}

Marina layout and design is multidisciplinary activity by nature. However, to include a new multidisciplinary element into the project, students will also be required to prepare a research report on the environmental aspects of marina construction and the critical environmental aspects of marine oil terminals that focuses on oil spills, a major reason for the development of MOTEMS $^{4}$.

\section{Summary and Conclusions}

This paper presents the development of coastal engineering design projects/studies in civil engineering Capstone courses at The Citadel. Specifically, a structural engineering professor has developed a project involving the design of a fixed marina dock system for gravity and environmental loading. An environmental engineering professor has included a separate component to consider the environmental aspects of marine oil terminals.

\section{References}

1. ICC, 2003. International Building Code, International Code Council, Falls Church, VA.

2. Department of Defense, 1 July 1999, "Mooring Design," Mil-HDBK-1026/4A, Washington, D.C.

3. Ferritto, J., Dickenson, S., Priestley N.,Werner, S., Taylor, C., Burke D., Seelig W., and Kelly, S., 1999, "Seismic Criteria for California Marine Oil Terminals," Vol.1 and Vol.2, Technical Report TR-2103-SHR, Naval Facilities Engineering Service Center, Port Hueneme, CA.

4. MOTEMS, 2005. The Marine Oil Terminal Engineering and Maintenance Standards, codified as Chapter 31F (Marine Oil Terminals), Title 24, California Code of Regulations, Part 2, California Building Code.

5. Harn, R.E., Displacement Design of Marine Structures on Batter Piles, 13th World Conference on Earthquake Engineering, Paper No. 543, August 2004.

6. ACI 318-05, 2005. Building Code Requirements for Structural Concrete (ACI 318-05) and Commentary (ACI 318R-05), American Concrete Institute, Farmington Hills, Michigan.

7. AASHTO, 2004. AASHTO LRFD Bridge Design Specifications, 3rd Edition, American Association of State Highway and Transportation Officials, Washington, D.C. 
8. Mays, T.W., and Bower, K.C., "Incorporating Multidisciplinary Components of Ocean and Marine Engineering in Traditional Civil Engineering Capstone Courses," Proceedings of the 2005 ASEE Annual Conference and Exposition, American Society for Engineering Education, 2005.

9. Mays, T.W., and Hill, T.E., 2007. "Rethinking Pile Ductility", Proceedings of the 2007 ASCE Structures Congress, Long Beach, CA (to be published). 